\title{
Prevalence and Determinants of Malnutrition Among Schoolchildren in Primary Schools in the Communes of Dixinn, Matam and Matoto, Conakry, Guinea, 2016
}

\author{
Touré Abdoulaye ${ }^{1,2,3,}$, , Kadio Kadio Jean-Jacques Olivier ${ }^{1}$, Camara Alioune ${ }^{1}$, Sidibé Sidikiba ${ }^{1}$, \\ Delamou Alexandre ${ }^{1}$, Kotchi Yao Emmanuel ${ }^{1}$, Barry Ibrahima Koolo ${ }^{4}$, Diallo Ibrahima Sory ${ }^{4}$, \\ Traoré Falaye $^{3,5}$, Magassouba Fodé Bangaly ${ }^{5}$, Khanafer Nagham ${ }^{6}$, Cissé Diao ${ }^{1}$, \\ Abro Awo Laurent ${ }^{1}$, Chambrier Cécile ${ }^{7}$, Etard Jean Francois ${ }^{8}$, Diallo Mamadou Pathé ${ }^{9}$ \\ ${ }^{1}$ Departement of Public Health, Faculty of Medicine-Pharmacy-Odonto-Stomatology, Gamal Abdel Nasser University of Conakry, Conakry, \\ Guinea \\ ${ }^{2}$ Center of Research and Training of Infectious Diseases, Gamal Abdel Nasser University of Conakry, Conakry, Guinea \\ ${ }^{3}$ National Institute of Public Health, Ministry of Public Health, Conakry, Guinea \\ ${ }^{4}$ Institute of Nutrition and Child Health, Ministry of Public Health, Conakry, Guinea \\ ${ }^{5}$ Departement of Pharmacy, Faculty of Medicine-Pharmacy-Odonto-Stomatology, Gamal Abdel Nasser University of Conakry, Conakry, \\ Guinea \\ ${ }^{6}$ Departement of Epidemiology and Infection Control, Edouard Herriot Hospital, Hospices Civils de Lyon, Lyon, France \\ ${ }^{7}$ Intensive Clinical Nutrition Service, Hospices Civils of Lyon, Lyon, France \\ ${ }^{8}$ Unit Recherche IRD UMI 233-INSERMU1175, Montpellier University, Montpellier, France \\ ${ }^{9}$ Departement of Pediatric, Faculty of Medicine-Pharmacy-Odonto-Stomatology, Gamal Abdel Nasser University of Conakry, Conakry, \\ Guinea
}

Email address:

abdoulayek2002@yahoo.fr(T. Abdoulaye)

${ }^{*}$ Corresponding author

To cite this article:

Touré Abdoulaye, Kadio Kadio Jean-Jacques Olivier, Camara Alioune, Sidibé Sidikiba, Delamou Alexandre, Kotchi Yao Emmanuel, Barry Ibrahima Koolo, Diallo Ibrahima Sory, Traoré Falaye, Magassouba Fodé Bangaly, Khanafer Nagham, Cissé Diao, Abro Awo Laurent, Chambrier Cécile, Etard Jean Francois, Diallo Mamadou Pathé. Prevalence and Determinants of Malnutrition Among Schoolchildren in Primary Schools in the Communes of Dixinn, Matam and Matoto, Conakry, Guinea, 2016. Central African Journal of Public Health. Vol. 4, No. 2, 2018, pp. 38-47. doi: 10.11648/j.cajph.20180402.12

Received: February 19, 2018; Accepted: March 19, 2018; Published: April 14, 2018

\begin{abstract}
Malnutrition leads to disruption of cognitive development and poor academic performance among children. However, few studies have been conducted in primary school to measure its burden and risk factors in Guinea. The objective of this study was to measure the prevalence of malnutrition and determine its associated factors among primary school children in Conakry, Guinea. A cross-sectional study was conducted from December $1^{\text {st }}, 2015$ to March $31^{\text {st }}, 2016$ among fifth grade primary school children in three communes of Conakry, Guinea. Children aged between 8 to 19 years were randomly selected using a two-stage sampling technic. Data on socio-demographic characteristics, of both children and their parents, and food habits were collected. The Z-scores of height-for-age and body mass index (BMI) were generated using SPSS macro 2007 developed by WHO for the analysis of anthropometric data for children aged between 5-19 years. Acute malnutrition was defined as a weight-for-height $z$-score $\leq-2.0$ standard deviation (SD) and a chronic malnutrition was considered as a height-forage $z$-score $\leq-2.0$ standard deviation (SD). A multivariable logistic regression analysis was conducted to assess factors associated with acute or chronic malnutrition among children. A total of 2,408 children were included in the analysis. The mean age was $12.5 \pm 1.8$ years, and $53.4 \%$ were female. The prevalence of acute malnutrition was $11.8 \%$ (95\% CI: 10.6-13.2) and that of chronic malnutrition was $13.7 \%(95 \% \mathrm{CI}: 12.1-14.9)$. Being a male (AOR $=1.88,95 \% \mathrm{CI}: 1.45-2.45, \mathrm{p}<.001)$, living in the communes of Dixinn ( $\mathrm{AOR}=3.78,95 \% \mathrm{CI}: 2.53-5.65, \mathrm{p}<.001$ ) and Matoto (AOR $=3.45,95 \%$ CI: 2.29-5.20, $\mathrm{p}$
\end{abstract}


$<.001$ ), as well as having a father who was a trader ( $\mathrm{AOR}=1.66,95 \% \mathrm{CI}: 1.15-2.41, \mathrm{p}=.007)$ were statistically significantly associated with acute malnutrition. Children attending Matoto schools (AOR $=3.72,95 \%$ CI: 2.68-5.16, $\mathrm{p}<.001$ ) were independently associated with chronic malnutrition. Acute and chronic malnutrition were common in primary school children in Conakry. Targeted awareness raising actions must be undertaken with the parents of those who have an important risk.

Keywords: Prevalence, Determinants, Malnutrition, Primary School, Guinea

\section{Introduction}

In developing countries, malnutrition and undernutrition are common despite the relative economic growth observed [1]. It can disrupt children's cognitive development and lead poor academic performance [2-4]. Malnutrition affects 200 million children worldwide including more than 20 million severe and acute malnutrition in developing countries $[5,6]$. In sub-Saharan Africa, various socio-economic factors have been associated with children's nutritional status, such as maternal and paternal education, parental income, and family assets [7]. A literature review on the nutritional status of children worldwide are mainly focus on children under 5 years of age. So, what about school-aged children? Schoolage children constitute an important part of the global population and more than 75 per cent live in developing countries [8]. This period of transition from childhood to adolescence requires a healthy and balanced diet for better health in adulthood, while physical, emotional and social changes occur among them [9]. In 2016, chronic malnutrition affected approximatively 154.8 million children under-five worldwide of which $90 \%$ occurred in Africa and Asia $[5,6]$. In addition, 20 million children suffer from severe acute malnutrition, most of whom live in South Asia and SubSaharan Africa [6]. Data on the nutritional status of schoolage children at the national level in developing countries are seldom [10]. Nevertheless, some researchers have investigated the nutritional status of school-age children in sub-Saharan Africa [11]. These different researches have focused on thinness, growth retardation, overweight and obesity as well as lifestyle and food behavior, micronutrients deficiencies [12-18]. In brief, these studies suggest that undernutrition is still prevalent in West Africa and severe malnutrition, micronutrient deficiencies, growth retardation, thinness or underweight are commonly diagnosed among children whose nutritional state had been evaluated [11]. Given its impact on health, and education, malnutrition is a major obstacle to human development and economic growth in poor countries and especially among the most vulnerable [19]. As a result, malnourished children are less likely to perform well in school and more likely to become malnourished adults and at higher risk of illness and premature death [19]. Researchers report that nutritional status might has a positive influence on cognitive development and academic performance [20-23]. In Guinea, data on the prevalence, risk factors and consequences of malnutrition are very rare. Among the few conducted, all of them only focused on children under five. One of these studies was highly disseminated through the 2012
Demographic and Health Survey. This study reported $10 \%$ of acute malnutrition, $31 \%$ of chronic malnutrition, and $20 \%$ underweight children of five years [24]. Additionally, the results of the SMART survey conducted in 2015 showed that $8 \%$ of children aged less than 59 months were malnourished acute and $25.9 \%$ of children aged 6-59 months chronically malnourished [25]. The determinants of nutritional status of school-aged children remain poorly documented in the study area. Thus, the present study was designed to measure the prevalence and analyze the determinants of malnutrition in fifth grade primary school children aged 8 to 19 years in three communes of Conakry, Guinea.

\section{Materials and Methods}

\subsection{Study Setting, Design and Population}

A cross-sectional study was carried out on 2,408 pupils, aged between 8-19 years and attending either public or private schools, in three communes of Conakry, Guinea. The study was conducted from December $1^{\text {st }}, 2015$ to March $31^{\text {st }}$, 2016. Conakry, the capital of Guinea is composed of five communes (Kaloum, Dixinn, Matam, Ratoma and Matoto) and has 1,660,973 inhabitants, $50 \%$ of them being females [26]. Each commune has its own Educational Direction. The present study was carried out in three Communal Education Directorates (Dixinn, Matam and Matoto)

Children of fifth grade from public or private primary schools in the three selected communes were included. Children of $5^{\text {th }}$ grade were targeted as they likely understand and easily answer a questionnaire as compared to those in the lower grades. Those in the $6^{\text {th }}$ grade were not included due to their unavailability regarding their exam preparations. Moreover, the level of children in the $5^{\text {th }}$ year is very close to that of the $6^{\text {th }}$ grade students. The programs taught are almost the same and the children of both classes are almost the same age.

\subsection{Sample}

$\mathrm{Al}$ least, 756 children per commune were required for this Study. In total, 2,268 children were included. These children were randomly selected using a two-stage sampling technic. The first sampling consisted of random selection of primary schools from the list provided by education directorates from the three communes. Second sampling, children of the $5^{\text {th }}$ grade presenting in the selected schools the day of the survey and accepting to be enrolled in this study were included. 


\subsubsection{Primary Schools' Selection for Participation}

Schools with at least 250 children were purposively selected. This choice was guided by concern not to be confronted with a lack of children given the heterogeneity observed in the enrolment of primary schools in Conakry. The list of schools was obtained from the communal education directorates. This list initially included 615 primary schools of which 212 met inclusion criteria. These schools were composed of 132 private and 80 public schools. The commune of Dixinn was composed of 92 schools divided into 75 private $(81.5 \%)$ and 17 public $(18.5 \%)$ schools. Matam had 94 schools including 68 private $(72.3 \%)$ and 26 public $(27.7 \%)$. Matoto had 429 primary schools including 386 private $(90.0 \%)$ and 43 public (10.0\%). At Matam 39 schools (nine private and four public schools) were included, 35 schools in Dixinn (16 public and 19 private) and finally in13 schools in Matoto (12 private schools and one public school) [27]. The number of public and private schools surveyed by commune was based on the weight of each commune (Figure 1).

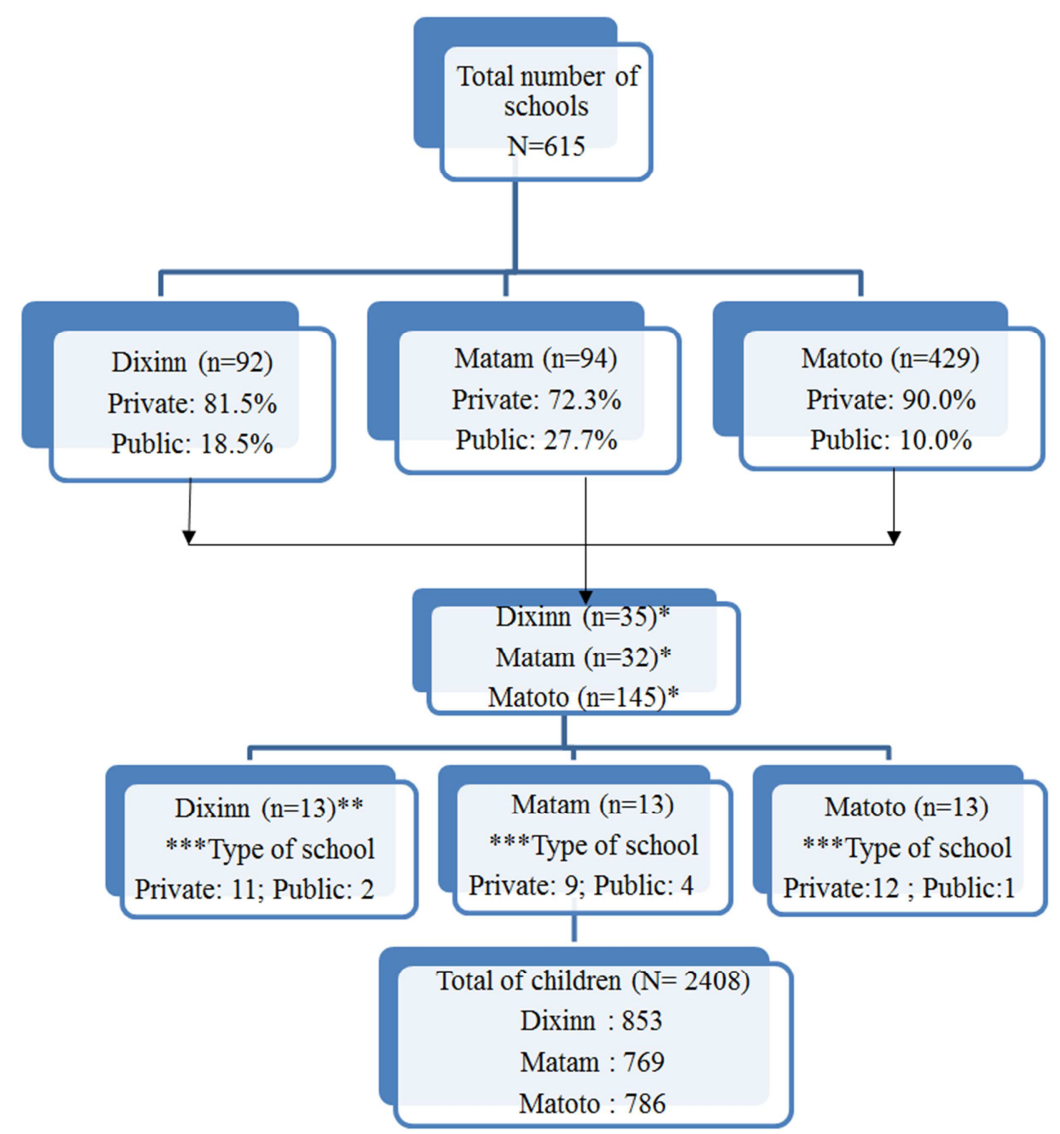

Figure 1. Schoolchildren' inclusion flowchart in the study.

*Schools with all primary classes and a minimum of 250 schoolchildren

** Number of schools to investigate $=$ Minimum size per commune $/$ Average number of children per class in Guinea [27]

Minimum size per commune $=831$ and average number of children per class in Guinea $=60$ [27]

*** Type of school per commune in total

Number of school type: Number of schools to investigate per commune $\mathrm{x}$ Rate of each type of school in the total number of schools by commune

\subsubsection{Choice of Children}

The study surveyed all $5^{\text {th }}$ grade children from the primary schools selected in each commune.

\subsection{Data Collections}

The data were collected using a standardized questionnaire including the sociodemographic characteristics of both the children and their parents (age, sex, weight, height, level of education, marital status, type of school attended, and food habits). Data on food habits included the food consumed (fruits, vegetables, meat, fish, liver, sweets and sweetened beverages) by the children during the last 7 days preceding the survey, as well as the foods regularly eaten by the parents and children' friends.

\subsection{Anthropometrics Measures}

The height of the children was measured twice while standing on a flat surface without shoes. The tape measure was placed at the heels of the children and at the back of the neck and the measure was read. When the difference between two successive measurements exceeded $0.5 \mathrm{~cm}$, a third measurement was made, and the two closest measurements were considered. Additionally, children were weighted by using an electronic scale of $0.1 \mathrm{~kg}$ accuracy. Two 
measurements were successively carried out. When the difference between the two measurements exceeded $0.2 \mathrm{~kg}$, a third measurement was made, and the two closest measurements were taken into consideration. After each series, a tare was used for the verification of the scale.

\subsection{Screening of Malnutrition Status}

All anthropometric measurements were done using WHO guide for anthropometric measurements by trained data collectors. Two anthropometric indices were used including the $\mathrm{z}$-score of the height for age and the $\mathrm{z}$-score of BMI for age were calculated according to the World Health Organization reference 2007 for 5-19 years [28]. Acute malnutrition was defined as a weight-for-height z-score less than -2.0 and a chronic malnutrition was considered as a BMI-for-age z-score less than -2.0 [28, 29]. Malnutrition was moderate when $z$-score was between -3.0 and -2.0 and sever when it was less than $-3.0[28,29]$. Z-scores for weight and height were generated using SPSS macro developed by WHO for the analysis of anthropometric data for children aged 5-19 years [29].

\subsection{Statistical Analysis}

Chi-square test or Fisher's exact test was used as the test of trend for compared categorical variables. The independent sample t-test was used for quantitative variables. Multivariate logistic regression model was performed to identify factors associated with malnutrition. All potential risk factors significant at the 0.20 level in univariate analysis were entered the model. The goodness-of-fit of the models was assessed by the Hosmer-Lemeshow test. After double data entry using Epidata 3.1, all statistical analyses were performed using the Statistical Package for Social Sciences (Version 21, Chicago, IL). A probability level of $\leq 0.05$ was considered statistically significant.

\subsection{Ethical Considerations}

Children'assent and parental oral consent were required. The study protocol was approved by the scientific committee of the Department of Public Health, Faculty of Medicine,
Gamal Abdel Nasser University of Conakry.

\section{Results}

\subsection{Socio-Demographic Characteristics of Children and Their Parents}

The study included 2,408 children in $5^{\text {th }}$ grade frequenting primary schools in three (3) communes (Dixinn, Matam and Matoto) of Conakry. Of these, 35.3\% were from Dixinn, $32.0 \%$ from Matam and $32.6 \%$ from Matoto. The mean age of children was $12.5 \pm 1.8$ years. The mean age of the parents was $46.8 \pm 10.0$ years for fathers and $36.4 \pm 7.8$ years for mothers. Among the fathers, $41.6 \%$ have informal activities, followed by public or private officers $30.9 \%$ and traders $14.7 \%$. Many of them have attended school, of which $23 \%$ had attended secondary level and 32.9\% high level. Among the mothers, $32.5 \%$ were traders, $30.9 \%$ were housewives. Of these, $23.6 \%$ had primary level, $17.3 \%$ a secondary level and $11.4 \%$ a high level.

\subsection{Food Habits of Children}

Children were asked about their daily foodhabits. Results showed that $54.7 \%$ took usually at least three meals, $34.8 \%$ took two meals, $8.9 \%$ took one meal. Their food habit included fish (98.9\%), beverages (98.1\%), candies $(97.3 \%)$, fruits $(87 \%)$, meat $(80.7 \%)$, and vegetables $(69.4 \%)$.

\subsection{Acute Malnutrition}

Tables 1 and 2 show the characteristics of children according to their nutrition status as well as those of their parents and their food habits. The proportion of acute malnutritionin children was $11.8 \%$ (95\% CI: 10.6-13.2), of which $3.7 \%$ (95\% CI: 3-4.5) suffered from a severe acute malnutrition and $8.1 \%$ (95\% CI: 7-9.2) from moderate acute malnutrition. The prevalence of acute malnutrition was different among the communes $(\mathrm{p}<.001)$ : Dixinn $(16.1 \%)$, Matoto (14.0\%) and Matam (4.7\%). It was higher in boys than girls $(15.4 \%$ vs. $8.7 \%, \mathrm{p}<.001)$.

Table 1. Characteristics of acute malnourished children and non-acute malnourished in three communes (Dixinn, Matam, Matoto) of Conakry, 2016.

\begin{tabular}{llll}
\hline Schoolchildren characteristics & Acute malnourished n (\%) & Non-Acute malnourished n (\%) & p-value \\
\hline Mean age & $12.5 \pm 1.8$ & $12.5 \pm 1.8$ & .51 \\
Gender & $172(15.4)$ & & $<.001$ \\
Boys & $111(8.7)$ & $946(84.6)$ & \\
Girls & $1169(91.3)$ & .11 \\
Pocket money & $6(2.1)$ & $64(3.0)$ & \\
No money & $97(34.3)$ & $592(28.0)$ & \\
Sometimes & $41(14.5)$ & $290(13.7)$ & .07 \\
Often & $139(49.1)$ & $1169(55.3)$ & $<.001$ \\
Always & & & \\
Type of school & $103(36.4)$ & $887(41.9)$ & \\
Public schools & $180(63.6)$ & $1228(58.1)$ & \\
Private schools & & & \\
Communes housing school & $137(16.1)$ & $714(83.9)$ & \\
Dixinn & $36(4.7)$ & $674(86.0)$ & \\
Matam & $110(14.0)$ & & \\
Matoto & &
\end{tabular}




\subsection{Chronic Malnutrition}

Table 3 and 4 show the characteristics of chronic malnourished children and chronic non-malnourished children as well as those of their parents and their eating habits. The prevalence of chronic malnutrition was $13.5 \%$ (95\% CI: $12.1-14.9)$, or $3.3 \%$ (95\% CI: $2.6-4)$ of severe chronic malnutrition and $10.2 \%(95 \%$ CI: 8.9-11.4) of moderate chronic malnutrition. The prevalence of chronic malnutrition was significantly different according to the communes $(\mathrm{p}<.001)$ : Matam (23.1\%), Dixinn $(10.3 \%)$ and Matoto $(7.6 \%)$. The prevalence of chronic malnutrition was higher among boys than girls $(17.0 \%$ vs. $10.4 \%, \mathrm{p}<.001)$.

Table 2. Characteristics of parents of acute malnourished children and acute non-malnourished children in three communes (Dixinn, Matam, Matoto) of Conakry, 2016.

\begin{tabular}{|c|c|c|c|}
\hline Parents' characteristics & Acute Malnourished n (\%) & Non-acute malnourished $\mathrm{n}(\%)$ & p-value \\
\hline Mean age of fathers & $46.2 \pm 9.9$ & $46.9 \pm 10.0$ & .26 \\
\hline Mean age of mothers & $36.3 \pm 7.4$ & $36.4 \pm 7.8$ & .86 \\
\hline Father profession & & & .003 \\
\hline Trader & $59(21.0)$ & $291(13.9)$ & \\
\hline Officers & $90(32.0)$ & $756(36.2)$ & \\
\hline Informal sector & $119(42.3)$ & $906(43.4)$ & \\
\hline Others professions & $7(2.5)$ & $75(3.6)$ & \\
\hline Unemployed & $6(2.1)$ & $61(2.9)$ & \\
\hline Mother profession & & & .71 \\
\hline Trader & $92(33.8)$ & $680(32.9)$ & \\
\hline Officer & $34(12.5)$ & $212(10.3)$ & \\
\hline Housewife & $84(30.9)$ & $653(31.6)$ & \\
\hline Informal sector & $35(12.9)$ & $332(16.1)$ & \\
\hline Student & $7(2.6)$ & $49(2.4)$ & \\
\hline Unemployed & $20(7.4)$ & $141(8.6)$ & \\
\hline Father education & & & .69 \\
\hline Illiterate & $11(3.9)$ & $111(5.3)$ & \\
\hline Arabic school & $71(25.4)$ & $479(23.0)$ & \\
\hline Primary & $36(12.9)$ & $273(13.1)$ & \\
\hline Secondary & $64(23.0)$ & $525(25.2)$ & \\
\hline University & $97(34.8)$ & $692(33.3)$ & \\
\hline Mather education & & & .35 \\
\hline Illiterate & $63(22.4)$ & $529(25.2)$ & \\
\hline Arabic school & $57(20.3)$ & $437(20.8)$ & \\
\hline Primary & $72(25.6)$ & $495(23.6)$ & \\
\hline Secondary & $48(17.1)$ & $402(19.2)$ & \\
\hline University & $41(14.6)$ & $233(11.1)$ & \\
\hline Matrimonial status of father & & & .57 \\
\hline Single & $8(2.9)$ & $67(3.3)$ & \\
\hline Married & $241(88.0)$ & $1848(89.9)$ & \\
\hline Divorced & $18(6.6)$ & $105(5.1)$ & \\
\hline Widower & $7(2.6)$ & $36(1.8)$ & \\
\hline Matrimonial status of mother & & & .50 \\
\hline Single & $5(1.8)$ & $42(2.0)$ & \\
\hline Married & $253(90.4)$ & $1907(91.4)$ & \\
\hline Divorced & $17(6.1)$ & $88(4.2)$ & \\
\hline Widow & $5(1.8)$ & $49(2.3)$ & \\
\hline
\end{tabular}

Table 3. Characteristics of chronic malnourished children and chronic non-malnourished children in three communes (Dixinn, Matam, Matoto) of Conakry, 2016.

\begin{tabular}{llll}
\hline Schoolchildren characteristics & Chronic malnourished $\mathbf{n}(\%)$ & Non-Chronic malnourished $\mathbf{n}(\%)$ & p-value \\
\hline Mean age of schoolchildren & $12.7 \pm 1.8$ & $12.4 \pm 1.7$ & .008 \\
Gender & $191(17.0)$ & $931(83.0)$ & $<.001$ \\
Boys & $134(10.4)$ & $1149(89.6)$ & .83 \\
Girls & & $58(2.8)$ & \\
Pocket money & $12(3.7)$ & $597(28.7)$ & \\
No money & $94(28.9)$ & $290(13.9)$ & .07 \\
Sometimes & $44(13.5)$ & $1135(54.6)$ & \\
Oftens & $175(53.8)$ & $845(40.6)$ & \\
Always & & $1235(59.4)$ & $<.001$ \\
Type of school & $149(45.8)$ & & \\
Publics school & $176(54.2)$ & & \\
Privates school & & & \\
Communes housing school & &
\end{tabular}




\begin{tabular}{llll}
\hline Schoolchildren characteristics & Chronic malnourished $\mathbf{n}(\%)$ & Non-Chronic malnourished n (\%) & p-value \\
\hline Dixinn & $88(10.3)$ & $765(89.7)$ \\
Matam & $177(23.1)$ & $589(76.9)$ \\
Matoto & $60(7.6)$ & $726(92.4)$ \\
\hline
\end{tabular}

Table 4. Characteristics of parents of chronic malnourished children and chronic non-malnourished children in three communes (Dixinn, Matam, Matoto) of Conakry, 2016.

\begin{tabular}{|c|c|c|c|}
\hline Parents' characteristics & Chronic malnourished n (\%) & Non-Chronic malnourished n (\%) & p-value \\
\hline Mean age of fathers & $48.3 \pm 10.9$ & $46.6 \pm 9.8$ & .005 \\
\hline Mean age of mothers & $37.3 \pm 8.7$ & $36.2 \pm 7.6$ & .02 \\
\hline Father profession & & & .003 \\
\hline Trader & $64(16.7)$ & $297(14.5)$ & \\
\hline Civil servant & $97(29.9)$ & $751(36.6)$ & \\
\hline Informal sector & $146(45.1)$ & $883(43.0)$ & \\
\hline Unemployed & $6(1.9)$ & $61(3.0)$ & \\
\hline Others professions & $21(6.5)$ & $61(3.0)$ & \\
\hline Mother profession & & & .02 \\
\hline Trader & $102(31.7)$ & $672(33.2)$ & \\
\hline Civil servant & $30(9.3)$ & $217(10.7)$ & \\
\hline Housewife & $123(38.2)$ & $617(30.5)$ & \\
\hline Informal sector & $47(14.6)$ & $321(15.9)$ & \\
\hline Student & $9(2.8)$ & $47(2.3)$ & \\
\hline Unemployed & $11(3.4)$ & $150(7.4)$ & \\
\hline \multicolumn{4}{|l|}{ Father education } \\
\hline Illiterate & $20(6.2)$ & $102(5.0)$ & .46 \\
\hline Arabic school & $82(25.5)$ & $470(23.0)$ & \\
\hline Primary & $45(14.0)$ & $264(12.9)$ & \\
\hline Secondary & $79(24.6)$ & $519(25.0)$ & \\
\hline University & $95(29.6)$ & $697(34.1)$ & \\
\hline Mother education & & & .94 \\
\hline Illiterate & $84(26.0)$ & $508(24.6)$ & \\
\hline Arabic school & $68(21.1)$ & $430(20.9)$ & \\
\hline Primary & $79(24.5)$ & $489(23.7)$ & \\
\hline Secondary & $58(18.0)$ & $393(19.1)$ & \\
\hline University & $34(10.5)$ & $241(11.7)$ & \\
\hline Matrimonial situation of father & & & .19 \\
\hline Single & $7(2.2)$ & $68(3.4)$ & \\
\hline Married & $297(92.5)$ & $1798(89.2)$ & \\
\hline Divorced & $15(4.7)$ & $108(5.4)$ & \\
\hline Widower & $2(0.6)$ & $41(2.0)$ & \\
\hline Matrimonial situation of mother & & & .52 \\
\hline Single & $4(1.2)$ & $43(2.1)$ & \\
\hline Bride & $301(93.2)$ & $1865(91.0)$ & \\
\hline Divorced & $13(4.0)$ & $92(4.5)$ & \\
\hline Widow & $5(1.5)$ & $50(2.4)$ & \\
\hline
\end{tabular}

Table 5. Multivariate analysis determinants of malnutrition among schoolchildren in three communes (Dixinn, Matam, Matoto) of Conakry, 2016.

\begin{tabular}{llll}
\hline Factors & Adjusted OR & (IC95\%) & p-value \\
\hline Acute malnutrition & & & \\
Gender & Reference & & $<.001$ \\
Girls & 1.88 & $(1.45-2.45)$ & \\
Boys & & & $<.001$ \\
Communes housing school & Reference & $(2.53-5.65)$ & $<.001$ \\
Matam & 3.78 & $(2.29-5.20)$ & .007 \\
Dixinn & 3.45 & & .16 \\
Matoto & & & .29 \\
Father profession & Reference & $(1.15-2.41)$ & .90 \\
Civil servant & 1.66 & $(0.92-1.69)$ & \\
Trader & 1.24 & $(0.23-1.55)$ & \\
Informal sector & 0.60 & $(0.36-2.44)$ & \\
Unemployed & 0.94 & & .09 \\
Others & & & \\
Chronic malnutrition & Reference & $(0.95-1.85)$ & \\
Gender & 1.33 & & \\
Girls & & & \\
Boys & & & \\
\hline
\end{tabular}




\begin{tabular}{llll}
\hline Factors & Adjusted OR & (IC95\%) & p-value \\
\hline Communes housing school & & & \\
Matoto & Reference & $(0.96-1.93)$ & .08 \\
Dixinn & 1.36 & $(2.68-5.16)$ & $<.001$ \\
Matam & 3.72 & & \\
Father profession & & & .85 \\
Civil servant & Reference & $(0.49-1.80)$ & .08 \\
Trader & 0.94 & $(0.31-1.07)$ & .26 \\
Informal sector & 0.58 & $(0.39-1.29)$ & .39 \\
Unemployed & 0.71 & $(0.23-1.78)$ & .03 \\
Others & 0.64 & $(1.00-1.03)$ & \\
Age of mother (continue) & 1.02 & & \\
\hline
\end{tabular}

\subsection{Factors Associated with Acute and Chronic Malnutrition}

The results of the multivariate analysis showed that male children were twice likely to be severely malnourished (AOR $=1.88,95 \%$ CI: $1.45-2.45, \mathrm{p}<.001), 5$ compared to girls. Children who attended schools in Dixinn (AOR $=3.78,95 \%$ CI: $2.53-5.65, \mathrm{p}<.001)$ and Matoto $(\mathrm{AOR}=3.45,95 \% \mathrm{CI}$ : 2.29-5.20, $\mathrm{p}<.001)$ were three times more likely to be severely malnourished (Table 5). Children whose father trade $(\mathrm{AOR}=1.66,95 \% \mathrm{CI}: 1.15-2.41, \mathrm{p}=.007)$ were twice likely to be acutely malnourished. For chronic malnutrition, children attending Matoto commune $(\mathrm{AOR}=3.72,95 \% \mathrm{CI}$ : 2.68-5.16, $\mathrm{p}<.001)$ were four times more likely to be chronically malnourished.

\section{Discussion}

This study measured the prevalence and analysed factors associated with acute and chronic malnutrition among children of fifth grade in primary schools in three communes of Conakry, Guinea. The overall prevalence of acute malnutrition was $11.8 \%$ including $3.7 \%$ of children suffering from severe acute malnutrition and $13.5 \%$ of chronic malnutrition, including $3.3 \%$ of children suffering from severe chronic malnutrition. According to the 2012 Demographic and Health Survey, $31 \%$ of children under five in Guinea suffer from chronic malnutrition and $10 \%$ from acute malnutrition [24]. The prevalence observed in this study amply demonstrates the extent of the phenomenon of acute and chronic malnutrition in primary schools in the city of Conakry. The frequency of thinness is a serious (10-14\%) threshold according to WHO indicators [30]. Moreover, this study showed the unexpected prevalence in an urban area, particularly the capital city, where living standard is supposed to be the highest in the country [24]. The low income of the household, the household and children food habits and their lifestyles could explain these figures of malnutrition observed in current study. Several studies reporting malnutrition on its various forms have been conducted among children in sub-Saharan Africa and elsewhere. A study conducted in Thad, reported $18.7 \%$ of chronic malnutrition among children aged between 6- 15 years [31]. A study conducted among children in urban and peri-urban areas of Ouagadougou reported a prevalence of chronic malnutrition at $8.8 \%$ and that of acute malnutrition at $1.7 \%$ [17]. A prevalence of acute malnutrition of $17.4 \%$ in primary and secondary schools in south western Nigeria had also been reported [32]. Another study among children aged between 5- 17 years old in the city of Dakar recorded 4.9\% of chronic malnutrition and $18.4 \%$ of acute malnutrition [33]. A study conducted in southern Ethiopia showed $10.3 \%$ of chronic malnutrition and $14 \%$ of acute malnutrition [34]. Other researchers reported high prevalence of $33.3 \%$ for chronic malnutrition and $31.0 \%$ for acute malnutrition among 12- to 18-year-olds attending 3 secondary schools in Nsukka, in the urban state of Enugu in Nigeria [35]. In Iran, a study in the northern region of the country revealed $4.93 \%$ of chronically malnourished schoolchildren and $5.13 \%$ of acute malnourished children [36]. Other researchers found $12.5 \%$ and $9.0 \%$ respectively of acute malnourished and chronically malnourished schoolchildren in Semnan (a province in the central region of Iran) [37]. These differences in prevalence compared to this study results may be explained by differential dietary intake, socio-economic and cultural differences rather than differences in their genetic potential [14].

The prevalence of chronic malnutrition, which is the most serious and whose consequences are almost irreversible, was different among the included communes. The highest proportions of chronic malnutrition were found in Matam (23.1\%) and Dixinn (10.3\%) communes than Matoto (7.6\%). In Guinea, socio-economic level of the household in which the child is living influences the prevalence of chronic malnutrition. The EDS data constructs the Household Economic Well-Being Index using data on dwelling characteristics and household holdings through a principal component analysis. The results showed that $41 \%$ of households are at level 2 on a scale of 1 (the poorest) to 5 (the richest). In current study, the prevalence of chronic malnutrition was different according to the residence of the children. This difference could be explained by socioeconomic determinants. Matam and Dixinn communes are coastal zones inhabiting artisanal harbours and the large market of Guinea. In the artisanal harbours of these communes, women practice daily small-scale trade and fish drying at the Madina market. The time devoted to these socio-economic activities means that they give practically no time to primary health care and prevention of malnutrition. We also hypothesize that access to health care facilities for the prevention and management of malnutrition could also 
explain this difference. Indeed, Matam commune, which has the highest proportion of chronic malnutrition, has only one public health centre for primary health care and malnutrition management.

This study showed that boys were more acutely malnourished than girls. Moreover, the results of multivariate analysis pointed out that male gender was an independent risk factor for acute malnutrition occurrence. Other studies carried out in Africa [38, 39] and elsewhere [40, 41] have reported similar results. Furthermore, chronic malnutrition seemed equally more frequent in boys. Similar trends were observed in EDS 2012, where the prevalence of chronic malnutrition was slightly higher among males than females (33\% versus 30\%) [24]. However, in studies conducted in India [42] and Makurdi in Nigeria [43] girls were more chronically malnourished than boys. These results can be explained by the fact that in Africa girls are closer to their mothers. They often attend the kitchen where they have easier access to food than boys.. While boys are not often engaged in cooking activities like girls therefore they are more exposed

This study has some limitations. The cross-sectional design should be considered as a limitation when interpreting the findings. Data on the food habits of the children would be useful if collected prospectively. Health-related data such as malaria, intestinal helminthiasis, anemia, vitamin A deficiency, highlighted as being correlated with undernutrition by some authors [44-46] and which have a negative impact on nutritional status [47, 48] and the cognitive development and academic performance of school children [49-51] were not evaluated in this study. Also, micronutrient intake in children was not assessed. However, to this knowledge, this study is one of the few of its kind using a large sample to assess malnutrition in primary schools in Conakry. It included over 2,000 children randomly selected. The study raises the issue of nutritional education and awareness raising based on the development of programs and strategies involving parents and schools to address malnutrition in primary schools in Conakry. In addition, the present study points the need for a nationwide study to better explore the issue. The results can also be used to set up an epidemiological surveillance system on the nutritional status of school children.

\section{Conclusion}

Despite public efforts in Conakry, the findings of this study shows that acute and chronic malnutrition were common in primary school of Conakry. The differences were found in the different communes and between boys and girls. Given the increasing prevalence of acute and chronic malnutrition in the schoolchildren, the current study suggests that preventive strategies and educational programs be implemented in Conakry primary school. Additionally, the study recommends that awareness-raising actions be undertaken with parents of those at high risk of malnutrition.

\section{Conflict of Interests}

The authors declare that they have no competing interests

\section{Acknowledgements}

The authors thank the staff of the Communal Educational Directorates. We also thank Stephanie Elsa Zohonon Kogbo Guédé, Koidjané Jean-Charles and Michel Wabo Boyom Kenmegue, as well as the staff of the schools who facilitated and contributed to the data collection.

\section{References}

[1] Muller O, Krawinkel M. Malnutrition et santé dans les pays en développement. Cmaj. 2005; 173 (3): 279-286.

[2] Brunser O. Nutrition du jeune enfant. Edit. Nestlé Nutrition SA et Raven Press Book Ldt, 1995.

[3] Singh M. Role of Micronutriments for Physical Growth and Mental Development. Indian Journal of Pediatrics. 2004; 71: 59-62.

[4] Latham MC, Cobos F. The effects of malnutrition on intellectual development and learning. American Journal of Public Health. 1971; 61: 1307-1324.

[5] United Nations Children's Fund (UNICEF). Strategy for improved nutrition of children and women in developing countries: a UNICEF policy review. New York, USA: 1991. Available:

http://repository.forcedmigration.org/show_metadata.jsp?pid= fmo:3066.

[6] MONDE: Aucune solution rapide pour la malnutrition et la faim, Available:

http://www.ipsinternational.org/fr/_note.asp?idnews $=5245 ; 13$ avril 2009.

[7] Owusu WB, Lartey A, de Onis M, Onyango AW, Frongillo EA. Factors associated with unconstrained growth among affluent Ghanaian children. ActaPaediatr. 2004; 93: 11151119.

[8] Ochola S, Masibo PK. Dietary intake of schoolchildren and adolescents in developing countries. Ann NutrMetab. 2014; 64 Suppl 2: 24-40.

[9] Srivastava A, Mahmood SE, Srivastava PM, Shrotriya VP, Kumar B: Nutritional status of school-age children - a scenario of urban slums in India. Arch Public Health. 2012; 70: $1-8$.

[10] Institut National de la statistique et de la démographie. Enquête Démographique et de Santé (EDS) 2003. Ouagadougou-Burkina-Faso. 2004.

[11] Latour C. État nutritionnel d'enfants d'âge primaire à Cotonou (Bénin) et à Ouagadougou (Burkina-faso). NUT 3035: MINIMÉMOIRES ET SÉMINAIRES. p31

[12] Kimani-Murage EW, Kahn K, Pettifor JM, Tollman SM, Dunger DB, Gómez- Olivé XF, Norris SA. The prevalence of stunting, overweight and obesity, and metabolic disease risk in rural South African children. BioMed Central Public Health. 2010; 10: 1-13. 
[13] Fetuga MB, Ogunlesi TA, Adekanmbi AF, Alabi AD. Growth Pattern of Schoolchildren in Sagamu, Nigeria Using the CDC Standards and 2007 WHO Standards. Indian Pediatrics. 2011; 48:523-528

[14] Senbanjo IO, Oshikoya KA, Odusanya OO, Njokanma OF. Prevalence of and Risk factors for Stunting among School Children and Adolescents in Abeokuta, Southwest Nigeria. Journal of Health, Population and Nutrition. 2011; 29: 364370.

[15] Akor F, Okolo S, Okolo A. Nutritional Status of Newly Enrolled Primary School Children in Jos-Plateau, Nigeria. Pakistan Journal of Nutrition. 2010; 9: 1166-1170.

[16] Adamu A, Adjei NKG, Kubuga CK. Effects of Dietary Patterns on the Nutritional Status of Upper Primary School Children in Tamale Metropolis. Pakistan Journal of Nutrition. 2012; 11: 591-609.

[17] Daboné C, Delisle HF, Receveur O. Poor nutritional status of schoolchildren in urban and peri-urban areas of Ouagadougou (Burkina Faso). Nutr J. 2011; 10: 34.

[18] Fiorentino M, Bastard G, Sembène M, Fortin S, Traissac P, Landais $\mathrm{E}$, Icard-Vernière $\mathrm{C}$, Wieringa $\mathrm{FT}$, Berger $\mathrm{J}$. Anthropometric and micronutrient status of school-children in an urban West Africa setting: a cross-sectional study in Dakar (Senegal). PLoSOne. 2013; 8 (12): e84328.

[19] Rashmi MR, Shweta BM, Fathima FN, Agrawal T, Shah M, Sequeira R. «Prevalence of Malnutrition and Relationship with Scholastic Performance among Primary and Secondary School Children in Two Select Private Schools in Bangalore Rural District (India) ». Indian J Community Med. 2015; 40 (2): 97-102.

[20] Abrahams Z, de Villiers A, Steyn NP, Fourie J, Dalais L, Hill $\mathrm{J}$, et al. What's in the lunchbox? Dietary behaviour of learners from disadvantaged schools in the Western Cape, South Africa. Public Health Nutr. 2011; 14: 1752-1758.

[21] Gibson RS, Manger MS, Krittaphol W, Pongcharoen T, Gowachirapant S, Bailey KB, et al. Does zinc deficiency play a role in stunting among primary school children in NE Thailand? Br J Nutr. 2007; 97: 167-175.

[22] Kristjansson B, Petticrew M, MacDonald B, Krasevec J, Janzen L, Greenhalgh T, et al. School feeding for improving the physical and psychosocial health of disadvantaged students. Cochrane Database Syst Rev. 2007; CD004676.

[23] Jomaa LH, McDonnell E, Probart C. School feeding programs in developing countries: impacts on children's health and educational outcomes. Nutr Rev. 2011; 69: 83-98.

[24] Institut National de la Statistique Guinée, Ministère du plan Guinée, ICF International. Enquête démographique et de santé et à indicateurs multiples (EDS-MICS 2012). 2012; 530: 165200 .

[25] Unicef Guinée, Ministère de la Santé et de l'Hygiène Publique Guinée. Enquête nationale nutritionnelle basée sur la méthodologie SMART, Juillet 2015, p25.

[26] Institut National de la Statistique. Résultats définitifs du troisième recensement général de la population et de l'habitation réalisé du $1^{\mathrm{er}}$ mars au 02 Avril 2014. Available: http://www.statguinee.org/PUB/rapports/INS_RGPH_2014_decret.pdf.
[27] Secrétariat permanent de la stratégie de réduction de la pauvreté (SP-SRP). Document de stratégie de réduction de la pauvreté DRSP III (2013-2015). Mai 2013. Available: www.srp-guinee.org.

[28] De Onis M, Onyango AW, Borghi E, Siyam A, Nishida C, Siekmann J. Development of a WHO growth reference for school-aged children and adolescents. Bull World Health Organ. 2007; 85 (9): 660-7.

[29] WHO. Growth reference 5-19 years: Application tools/macro SPSS. Available http://www.who.int/growthref/tools/en/.

[30] WHO. Nutrition Landscape Information System (NLIS) country profile indicators: interpretation guide. Geneva 2010. p51.

[31] Beasley M, Brooker S, Ndinaromtan M, Madjiouroum EM, Baboguel M, Djenguinabe E, Bundy DA. First nationwide survey of the health of schoolchildren in Chad. Trop Med Int Health. 2002; 7 (7): 625-3.

[32] Senbanjo IO, Oshikoya KA, OdusanyaOO, Njokanma OF. Prevalence of and risk factors for stunting among school children and adolescents in Abeokuta, southwest Nigeria. J Health PopulNutr. 2011; 29 (4): 364-70.

[33] Fiorentino M, Bastard G, Sembène M, Fortin S, Traissac P, Landais $\mathrm{E}$, Icard-Vernière $\mathrm{C}$, Wieringa $\mathrm{FT}$, Berger $\mathrm{J}$. Anthropometric and micronutrient status of school-children in an urban West Africa setting: a cross-sectional study in Dakar (Senegal). PLoS One. 2013; 8 (12): e84328.

[34] Wolde M, Berhan Y, Chala A. Determinants of underweight, stunting and wasting among schoolchildren. BMC Public Health. 2015; 15: 8.

[35] Ayogu RN, Nnam NM, Ibemesi O, Okechukwu F. Prevalence and factors associated with anthropometric failure, vitamin A and iron deficiency among adolescents in a Nigerian urban community. Afr Health Sci. 2016; 16 (2): 389-98.

[36] Veghari G. The relationship of ethnicity, socio-economic factors and malnutrition in primary school children in north of Iran: a cross-sectional study. J Res Health Sci. 2012; 13 (1): 58-62.

[37] Karimi B, Ghorbani R, Niaki MA. Malnutrition and some related factors in primary school children, Semnan, Iran. J Egypt Public Health Assoc. 2016; 91 (4): 174-178.

[38] Mukuddem-Petersen J, Kruger HS. Association between stunting and overweight among 10-15-y-old children in the North West Province of South Africa: the THUSA BANA Study. Int J Obes Relat Metab Disord. 2004; 28 (7): 842-51.

[39] Semproli S, Gualdi-Russo E. Childhood malnutrition and growth in a rural area of Western Kenya. Am J Phys Anthropol. 2007; 132 (3): 463-9.

[40] Rao VG, Yadav R, DollaCK, Kumar S, Bhondeley MK, Ukey M. Undernutrition \& childhood morbidities among tribal preschool children. Indian J Med Res. 2005; 122 (1): 43-7.

[41] Mikki N, Abdul-Rahim HF, Awartani F, Holmboe-Ottesen G. Prevalence and sociodemographic correlates of stunting, underweight, and overweight among Palestinian school adolescents (13-15 years) in two major governorates in the West Bank. BMC Public Health. 2009; 9: 485. 
[42] Chowdhury SD, Chakraborty T, Ghosh T. Prevalence of undernutrition in Santal children of Puruliya district, West Bengal. Indian Pediatr. 2008; 45 (1): 43-6.

[43] Goon DT, Toriola AL, Shaw BS, Amusa LO, Monyeki MA, Akinyemi O, Alabi OA. Anthropometrically determined nutritional status of urban primary schoolchildren in Makurdi, Nigeria. BMC Public Health. 2011; 11: 769.

[44] Erismann S, Knoblauch AM, Diagbouga S, Odermatt P, Gerold J, Shrestha A, Tarnagda G, Savadogo B, Schindler C, Utzinger J, Cissé G. Prevalence and risk factors of undernutrition among schoolchildren in the Plateau Central and Centre-Ouest regions of Burkina Faso. Infect Dis Poverty. 2017; 6 (1): 17.

[45] Pullan RL, Gitonga C, Mwandawiro C, Snow RW, Brooker SJ. Estimating the relative contribution of parasitic infections and nutrition for anaemia among school-aged children in Kenya: a subnational geostatistical analysis. BMJ Open. 2013; $3(2)$.

[46] Jardim-Botelho A, Queiroz Gurgel R, Simeone Henriques G,
Dos Santos CB, Afonso Jordão A, Nascimento Faro F, Silveira Souto FM, Rodrigues Santos AP, Eduardo Cuevas L. Micronutrient deficiencies in normal and overweight infants in a low socio-economic population in north-east Brazil. Paediatr Int Child Health. 2016; 36 (3): 198-202.

[47] Awasthi S, Bundy D. Intestinal nematode infection and anaemia in developing countries. BMJ. 2007; 334 (7603): 1065-6.

[48] Casapía M, Joseph SA, Núñez C, Rahme E, Gyorkos TW. Parasite risk factors for stunting in grade 5 students in a community of extreme poverty in Peru. Int J Parasitol. 2006; 36 (7): $741-7$

[49] Singh M. Role of micronutrients for physical growth and mental development. Indian J Pediatr. 2004; 71 (1): 59-62.

[50] Taras H. Nutrition and student performance at school. J Sch Health. 2005; 75 (6): 199-213.

[51] Florence MD, Asbridge M, Veugelers PJ. Diet quality and academic performance. J Sch Health. 2008; 78 (4): 209-15. 